\title{
DO POLICY MAKER CREATES FINANCIAL INNOVATION AND SUPPORT GROWTH?
}

\author{
Suwinto Johan \\ Departement of Management \\ Sekolah Tinggil Ilmu Ekonomi Wiyatamandala \\ suwintojohan@gmail.com
}

\begin{abstract}
The financing industry has grown rapidly for more than 40 years of enactment of the 3 ministerial regulations in 1974. The regulations that governing this industry have also been updated several times by the related authorities from time to time, directly under the supervision of the Minister of Finance to Capital Market Supervisory Agency and Financial Institution of Indonesia (Bapepam LK) until now by the Financial Services Authority (OJK). The type of businesses that can be run also has grown from the lease type of financing to capital financing, multipurpose financing and investment financing at this time. This study examines the development of financing industry in line with the regulatory changes. The study conducted a qualitative study as literature and secondary. This study found that the growth of financing industry can be divided into 3 period in accordance with the regulations that have been issued. These three periods are 1974-1988, 1988-2015 and 2015-2017 (current). Also, this study found that changing regulation has supported the development of the financing industry from time to time. The further study is needed to examine the development of financing industry since the issuance of PJOK in 2015.
\end{abstract}

Keyword : Deregulation, Financing, Regulation

\section{Background}

Indonesia financing industry begins with the presence of government regulation called Join Decree (Surat Keputusan Bersama) of the Minister of Finance, Minister of industry and Minister of Trade of Republic of Indonesia No. KEP-122/MK/2/1974, No. 32/M/SK/2/74 and $30 / \mathrm{Kpb} . / 1 / 74$ concerning about leasing companies. The companies license is given by the Minister of Finance with consideration from Bank Indonesia. This regulation becomes the basis for the presence of several leasing companies that finance the motor vehicles. One of them is the presence of OBUL which is a joint venture between Yayasan Kesejahteraan Karyawan Bank Indonesia and Orix, Japan on April 21, 1975.

Hire purchase business for purchasing consumer goods with installment is marked by the Trade and Cooperative Regulation No. 34/KP/II/80 about Hire Purchase Business License, Sale and Purchase with installment and Renting. This regulation allows the trading company to run a hire purchase business. At this time, the car trading companies, especially used cars, established hire purchase companies to support the sales of used cars.

Licensing and expansion of the financing company's business is expanded with the issuance of KEPRES (Presidential Decree) No.39 in 1988, and No. 61 in 1998 about the Financing Institution. In this KEPRES (Presidential Decree) the Licensing of Financing Institution is divided by Consumer Financing Company, Credit Card Financing Company, Factoring Financing Company, Venture Capital Financing Company and Leasing Financing Company.

The expansion of financing activities was expanded again on the Regulation of the Financial Services Authority (OJK) No. 29/PJPK.05/2014 about the operation of the financing company's business. Financing companies are allowed to expand their activities by changes the type of businesses that can be run from credit cards, leasing, consumer financing, 
and factoring into multipurpose financing, investment financing and working capital financing. This expansion as shown in Table 1.

Table 1 Types of Financing

\begin{tabular}{|l|l|l|l|}
\hline No. & \multicolumn{1}{|c|}{ Financing } & \multicolumn{1}{c|}{ Type } & \multicolumn{1}{c|}{ Tenor } \\
\hline 1. & Multipurpose & $\begin{array}{l}\text { Lease: Direct Lease } \\
\text { Installment Finance }\end{array}$ & \\
\hline 2. & Investment & $\begin{array}{l}\text { Lease: Direct Lease and Sale and } \\
\text { Leaseback } \\
\text { Factoring with Recourse } \\
\text { Installment Financing } \\
\text { Project Financing }\end{array}$ & More than 2 years \\
\hline 3. & $\begin{array}{l}\text { Working } \\
\text { Capital }\end{array}$ & $\begin{array}{l}\text { Lease: Sale and Leaseback } \\
\text { Factoring } \\
\text { Working Capital Facility }\end{array}$ & Less than 2 years \\
\hline
\end{tabular}

Financing companies experienced several ups and downs along with the development of the national economy such as in 1990-1991, 1996-1997 and 2007-2008. The Regulation of Financing Companies also experienced some changes in term of supervision, from BapepamLK to the Financial Services Authority as well as other matters such as the source of funding and the maximum allowable loan value.

\section{Researches}

According to Storey and Easingwood (1999), the development of new products will be successful if started by considering the benefits to be gained from the company that developed it. The company's benefit that mentioned in the research are the sales to be gained, the market share, and the profit generated.

Cole, Sampson and Zia (2010) found that penetration of a financial product will extremely depend on the financial literacy of the consumer This research was conducted on people in Indonesia and India in 2009-2010.

According to Ansoff (1990), the company's strategy to penetrate the existing consumers and new consumers along with new products is a new and diversified product development strategy.

Table 2: Regulation Development of Financing Companies

\begin{tabular}{|l|c|l|l|}
\hline No. & \multicolumn{1}{|c|}{ Period } & \multicolumn{1}{|c|}{ Foundation of Regulations } & \multicolumn{1}{|c|}{ Type of Business } \\
\hline 1 & $1974-1988$ & $\begin{array}{l}\text { Joint Decree of the Minister of } \\
\text { Finance, Minister of Industry and } \\
\text { Minister of Trade of Republic of } \\
\text { Indonesia No. KEP-122/MK/2/1974, } \\
\text { No. 32/M/SK/2/74 and 30/Kpb./1/74 }\end{array}$ & Lease \\
\hline 2 & $1980-1988$ & $\begin{array}{l}\text { Trade and Cooperative Regulations } \\
\text { No. 34/KP/II/80 }\end{array}$ & Hire Purchase \\
\hline 3 & $1988-2015$ & $\begin{array}{l}\text { Presidential Decree No.39 YEAR } \\
1988 \text { and No. 61 YEAR 1998, Decree } \\
\text { of Minister of Finance NO. } \\
607 / K M K .017 / 1995, \text { Regulation of } \\
\text { the Minister of Finance } \\
84 / \text { PMK.012/2006* }\end{array}$ & $\begin{array}{l}\text { Lease, Consumer } \\
\text { Cards, and Factoring }\end{array}$ \\
\hline 4 & $2015-$ present & Regulation of OJK (Finance Services & Multi-Purpose \\
\hline
\end{tabular}




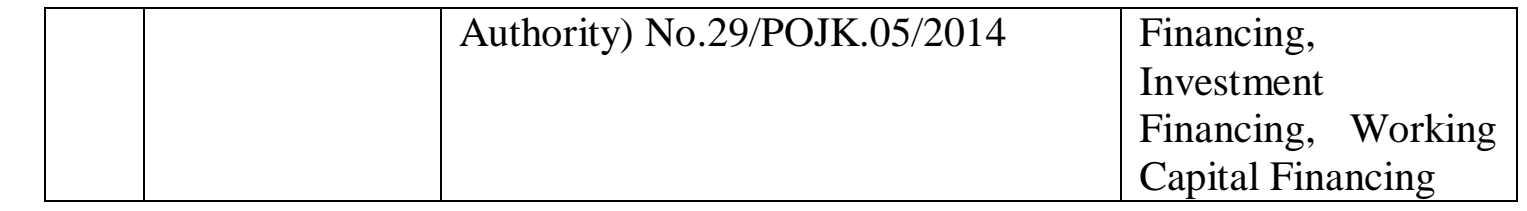

Note: * Other regulations during period of $1988-2015$

This study will examine the innovation of financing products that increase the interest and fulfillment of the needs of people in Indonesia. The discussion will be based on the development of financing industry in 3 stages of business expansion and financing products from 1974 to 2016. The discussion will be divided into 3 periods from 1974 to 1988,1998 to 2015 and 2015 to the present. This study will also discuss about the development of product innovation in other countries as a comparison. In section 4, research will provide conclusions and suggestions.

\section{Methodology and Data III.1. Methodology}

This research used literature study and descriptive study methods. Descriptive study method aims to collect actual information by describing the existing symptoms, identify the condition that occur, make evaluations and determine what happens. This descriptive study method is used to systematically describe the fact of financing industry from 1974-2017. This method focuses on the observations that have occurred and conclude it.

\section{III.2. Data}

This research used secondary data obtained from various institutions and financial data published by related authorities and associations of financing companies. The researcher prepared this paper based on:

1. Government policies and regulations including from the Financial Services Authority issued regarding financing or leasing industry from 1974-2017

2. Financing industry data from 1974-2017

3. Public information that can be obtained from various sources

\section{Analysis}

\section{IV.1. Period of 1974 - 1988}

From 1974 to 1980, the financing industry in Indonesia focused on leasing activities. The sales of automotive industry, especially Japan, began to develop in Indonesia. The establishment of financing institution was to support the sales of automotive industry. In 1975, PT Pembangunan Armada Niaga Nasional (PANN) was established, which is a limited liability company. The term of leasing that we know nowadays, although in fact to be intended as consumer financing or consumer credits.

In 1980, the government issued a regulation about the permission od the Hire Purchase and buy-sell with installment and leases. Some automotive sales companies use this scheme to support the sale of their vehicles, especially the sale of used vehicle. The business was growing rapidly and was in the shade of the trade minister at the moment. The establishment of leasing and buying-selling with installment was happened in each city and not applicable nationally. Entrepreneurs will set up their own limited company's license to support their sales. It made difficult for some actors in this industry to have company in every city. One of the players in this industry at that time was Olympia Group (Olympindo).

A few years later, several large groups began to established financing institution to support the automotive sales. In 1982, PT. Astra International established PT. Rahardja Sedaya (currently know as PT Astra Sedaya Finance) which is the forerunner od Astra Credit 
Companies (ACC). ACC support the sales of automotive of Astra Group for brands under Astra distributor.

In the beginning, they cooperated with government banks including PT. Bank Negara Indonesia 1946 and others. PT. Indomobil in cooperation with PT. BNI 46 established PT. Swadharma Indotama Finance. Also, Astra group in cooperation with PT BNI 46 established PT. Swadharma Bakti Sedaya Finance, Astra Group with PT. Bank Bumi Daya established Estika Sedaya Finance and in cooperation with PT. Bank Dagang Negara established PT. Stacomitra Sedaya Finance.

In this period, financing institutions are still focusing on financing the automotive industry that was growing rapidly at that time.

\section{IV.2. Period of $1988-2015$}

In 1988, the President of Indonesia issued Presidential Decree no. 61/1988 that extends the leasing business license from leasing to incorporate factoring, consumer financing, venture capital and credit card licenses into the non-bank financing industry. Since the issuance of this regulation, the industry players have begun to enter into other businesses besides leasing. In its early stages, factoring rapidly growing up to the 1990s.

In the early 1990s to 1997, consumer of financing business has grown rapidly and supporting the automotive sales of both 2 wheels and 4 wheels. Leasing also grew rapidly during this period. The sales of 4 wheels vehicles grew by redeeming 500,000 units of sales with an increasing share of financing. Financing companies also known as companies that have easier and faster process compared to credit applications through bank.

In December 1996, government issued regulations about restrictions on foreign loans, minimum capital to be placed, the maximum value of investment in other financial industries and others. It was because financing companies were used as holding companied by several groups of companies at that time.

In 1997, the financing industry experienced a significant decline due to the economic crisis that hit Indonesia. At that time, more than 70 financing companies' licenses were revoked. The financing industry has declined until 2002 in line with the slowing down of national economy as well as automotive industry.

The financing industry was growing rapidly in all business licenses including credit cards that also run by several financing companies such as GE Capital Indonesia and Dinners. Consumer financing was growing rapidly in line with the increasing in the sales of 4 wheels vehicle that reached 1 million units and also 2 wheels vehicles that reached 8 million units. Automotive sales began to decline in 2014-2016. It resulted in a decline in financing companies' industrial assets.

Until 2008, leases have declined along with the global downturn that dampened demand for commodities that become the main source of the industry. In that time, leases focused on heavy equipment related to export-oriented mining and plantations. This decline lasts until 2015.

In this period, financing companies refocused on supporting the sales of the automotive and heavy equipment industries.

\section{IV.3. Period of 2015 - Present}

The Financial Services Authority (OJK) issued a regulation that expands the business license of financing industry by the end of 2015. With a business license, a financing company may enter other types of business such ass working capital financing, infrastructure financing, and get fee income through cooperation sales. This expansion makes the financing industry more attractive, and opens other types of business besides the dependence on the automotive industry that has been going on since 1974. 
Financing companies begin to open up on the goods financing other than services. Financing companies began to enter infrastructure financing such as port financing, marine financing and smelter financing and others.

Financing companies also begin to start to finance services' buyers such as tuition fees for graduate financing, tourism visit financing, and religious visit financing.

\section{IV.4. Industrial and Products Development for 3 Periods}

The researcher concludes that with the expansion of the financing area as well as the financing products, the financing growth will be better and more diversified. The dependence on certain industry will be smaller and growth will be more sustainable.

The risk of bad loans also will be more diversified into different types of products. Initially, financing companies were really dependent on automotive sales. Automotive sales are really dependent on inflation, interest rates and fuel prices. It there are fluctuations on interest rates and fuel prices, then the amount of financing will be decrease.

The bargaining power of financing companies to the automotive suppliers/dealers will also get better. During this time, financing companies receive pressure from suppliers/dealers because if this financing dependence.

Table 3: Financing Products

\begin{tabular}{|c|l|l|}
\hline Period & \multicolumn{1}{|c|}{\begin{tabular}{c}
\multicolumn{1}{c|}{ Types of } \\
Products/Services
\end{tabular}} & \multicolumn{1}{c|}{ Anlysis } \\
\hline $1974-1988$ & $\begin{array}{l}\text { Automotive and Heavy } \\
\text { Equipment }\end{array}$ & $\begin{array}{l}\text { The focus of financing is solely on } \\
\text { automotive and dependent on } \\
\text { automotive }\end{array}$ \\
\hline $1988-2015$ & $\begin{array}{l}\text { Automotive, Heavy } \\
\text { Equipment, Credit Card, } \\
\text { Factoring business. }\end{array}$ & $\begin{array}{l}\text { Diversification to credit cards and } \\
\text { factoring, business potential is } \\
\text { growing. However, automotive } \\
\text { dependence is getting higher. }\end{array}$ \\
\hline 2015-present & $\begin{array}{l}\text { Automotive, Heavy } \\
\text { Equipment and Machines } \\
\text { of the Micro, Small, and } \\
\text { Medium Enterprise } \\
\text { (UMKM), Credit Card } \\
\text { Factoring of Trade, } \\
\text { Maritime, Infrastructure, } \\
\text { Services (Tuition fee, } \\
\text { tourism cost), UMKM } \\
\text { Working Capital } \\
\text { Financing }\end{array}$ & $\begin{array}{l}\text { Diversification is expanded with a lot } \\
\text { of business potential to run. Reduce } \\
\text { equipment. }\end{array}$ \\
\hline
\end{tabular}

\section{IV.5. Product Innovation Developments in Other Countries}

Expansion and changes in financial industry licenses have also occurred in some countries. Glass Steagall Act 1933 that changed the structure of banking business in the United States. The Glass Steagall Act regulates the consolidation of the financial industry by separating commercial banks and investment companies. At that moment, the consolidation of financial industry was considered as the cause of the 1928 global recession. 
In 1999, the Gramm-Leach-Bliley Act (BLBA) awarded the establishment of Bank Holding Company whereby banks, investment companies and insurance companies were allowed to consolidate. It was considered as the cause of the global crisis in 2008. This regulation is the basis for the financial industry consolidation in the United States after the crisis.

The regulations will change according to the demand of the times, and the industry players' ability to adapt to the challenge.

\section{Challenge of Financing Industry V.I. Funding Challenges}

Financing company has limitation in obtaining funds, since the license of the financing company is allowed. Financing company has a funding dependence on banks. It is allowed to issue bonds to investors, but it has limited ability to do so.

Issuance of bonds requires some things such as securities rating, the number of efficient issuance, processes that require openness and professional engagement. Not all financing companies have ability to do this. Financing companies with banking and large group shareholders will have these capabilities. From the 200 financing companies, only about 20 companies that have ability to issue bonds.

Another alternative, is the search for capital through shares offering in the capital market. From 200 financing companies, there are only 15 financing companies that listed on the Indonesia Stock Exchange.

From the descriptions above, the funding difficulties of financing companies, although other business lines have opened. Banks will always ask for collateral that is unique and easy to execute. If executed, the collateral is easy to resell to cover the outstanding balance.

\section{V.II. Business Model Challenges}

For almost 30 years, the business model of financing company is dependence on supplier/dealer, with indirect marketing. With this new business model, then the change of mindset and business model become important in the financing company.

Behavioral approach to intermediary becomes irrelevant, direct approach to the consumer becomes the key. Direct marketing with service sales, fast and responsive services is important in this matter. It becomes a challenge for the financing companies.

The development of new products also required literacy to other industries and communities, so that consumers know the availability of the financing product to support them.

\section{V.III. Risk Challenges}

Financing companies have a long experience in handling automotive financing. Financing companies need time to experience in credit approval, appraisal of collateral goods, execution of guarantee goods up to regulation related to financing scheme.

Financing companies need to learn how to assess creditworthiness in the maritime industry, infrastructure, machinery, and others. Besides, financing companies need to study related regulations, collaterals, binding procedures, and documents required for legal binding.

Maritime financing will require knowledge of maritime legislation. Machinery financing will require knowledge about industry such as laws on interference, pollution, order and other laws. Infrastructure financing requires knowledge about government regulations that related with infrastructure.

In addition to the legal risk factors, financing companies also face other risk challenges including execution risk, security risk registration such as fiduciary. 
Financing companies need to prepare all of these infrastructures together industrially to deal with all these risks by sharing knowledge through associations and working together through syndicated financing.

\section{V.VI. Human Resource Challenges}

The next challenge is the readiness of human resources to enter a different business era. So far, human resources only focus on automotive financing and indirect marketing.

Financing companies need training and human resources preparation to enter the new business model era. They also need a long time to prepare the human resources. As a way out, financing companies can take human resources from other industries including banking and consumer industries; that are accustomed to direct distribution and marketing channels.

\section{Conclusion}

Based on the analysis result above, it can be concluded that,

1. Expansion of financing permit or license by the regulator will increase the financing growth and financing industry's contribution to the national economy for almost 30 years.

2. The internal preparation of financing industry is needed, primarily related with the availability of funding sources, business model changes, improving the quality of human resources and knowledge of risks.

3. Close cooperation of fellow financing companies is needed in an association and with support of related authorities.

4. Financial literacy is required for the socialization of new type of business line in financing companies.

\section{References}

Ansoff I, McDonnel E (1990), Implanting Strategic Management, $2^{\text {nd }}$ Edition. London (GB); Prentice Hall.

Cole, Shawn; Sampson, Thomas and Zia, Bilal (2010) Prices or Knowledge? What Drives Demand for Financial Services in Emerging Markets? Working Paper 09-117 Harvard Business School

Iqbal Hasan M, (2002) Pokok-Pokok Materi Metodologi Penelitian dan Aplikasinya. Penerbit Ghalia Indonesia : Jakarta.

Johan, Suwinto, (2013) Analisis Aliansi Akuisisi dan Determinasi Pada Industri Perusahaan Pembiayaan Indonesia, Disertasi, Institut Pertanian Bogor

KEPPRES No.39 TAHUN 1988 tentang Lembaga Pembiayaan

KEPPRES No. 61 TAHUN 1998 tentang Lembaga Pembiayaan

Keputusan Menteri Keuangan NO. 607/KMK.017/1995

Peraturan Perdagangan dan Koperasi No. 34/KP/II/80 tentang Perizinan Kegiatan Usaha Sewa Beli (Hire Purchase)

Peraturan Menteri Keuangan 84/PMK.012/2006

Peraturan Otoritas Jasa Keuangan No. 29/POJK.05/2014 tentang penyelenggaraan usaha perusahaan pembiayaan

Peraturan Otoritas Jasa Keuangan Nomor 30/POJK.05/2014 tentang tata kelola perusahaan yang baik bagi perusahaan pembiayaan

Storey, Chris dan Easingwood, Christopher J., (1999) Types of New Product Performance: Evidence from the Consumer Financial Services Sector, Journal of Business Research 46, 193-203, Elsevier Science Inc. 
Surat Keputusan Bersama Menteri Keuangan, Menteri Perindustrian dan Menteri Perdagangan Republik Indonesia No. KEP-122/MK/2/1974, No. 32/M/SK/2/74 dan $30 / \mathrm{Kpb} . / 1 / 74$ mengenai perusahaan sewa guna usaha 


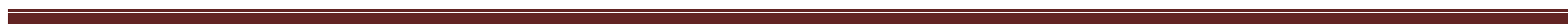
$\cdot$ 